
Y
VERSITA
UNIVERSITETI I EVROPËS JUGLINDORE

\title{
CHALLENGES FOR LEARNERS/ TEACHERS IN THE ESP COURSE FOR LEGAL STUDIES
}

\author{
Basri Saliu \\ $\mathrm{PhD}$ Candidate -SEEU/LC \\ Email: b.saliu@seeu.edu.mk \\ DOI: 10.2478/seeur-2013-0001
}

\begin{abstract}
The article aims to reveal the challenges both ESP learners and teachers encounter during learning/teaching specific content and specific vocabulary of English for Legal studies. The main issue which is anticipated to be a challenge for teachers in this course is often inadequate knowledge of a specialist field. As far as learners are concerned we anticipate that in most ESP courses they are not prepared for professional communication in English on the area of their field. These anticipated results are the basic hypothesis of our manuscript to focus on. The study is aiming at finding out and answering these two questions. For this purpose the survey was carried out at SEEU, English for Legal Studies faculty. Both teachers and learners were asked about their attitude and preparedness towards ESP course.
\end{abstract}

Key words: ESP, content, reveal, challenges, specialist field 


\section{Introduction}

Most teachers teaching ESP course have a dilemma and ask themselves the question whether they are teaching English for Law or teaching law in English. Everyone can agree that language for law, is a different language. Even if you are a native speaker with a very high level of academic skills, yet English for law seems a different language for us. Teaching ESP is meant at developing students' skills of professional communication in English depending on the area of their professional field. It means that such teaching should be connected to students' particular specialization. Therefore, English for specific purpose includes specialized programs which are designed to develop the communicative use of English in a specialized field of science, work or technology.

ESP is an approach to language teaching which aims to meet the needs of particular learners. This means in practice that much of the work done by ESP teachers is concerned with designing appropriate courses for various groups of learners (Hutchinson and Waters, 1996). Therefore, students learn English for specific purposes and the purpose of ESP is to prepare a specialist to be able to use a foreign language as the main communications means in communicating and cooperating with foreign partners in the professional field and real-life situations. So, teaching/learning ESP is said to be specialty-oriented as it is submitted to specific (professional) needs of the students.

On the other hand making use of a foreign language the student acquires profound professional knowledge as well. Thus, it is difficult to determine where the language learning ends and where subject learning starts or vice versa.

At SEEU students of different study programs are taught English using subject-matter approach

,depending on the study program. Specific teaching/learning materials, specific methods of teaching depending on students' future jobs are developed and applied.

\section{Literature Review}

In developing this paper I conducted a multidisciplinary analysis of the research literature, and examined studies that helped to increase our understanding of the ESP and shape the ideas for this study.

One of the authors I relied on in most of my paper is Hutchinson and Waters (1996).These two authors claim (1996) that the growth of ESP was brought up by a combination of three important factors: the expansion of demand for English to suit particular needs and development in the field of linguistics and educational psychology. All three factors seemed to point towards the need for increased specialization in language learning. Tell me what you need English for and I will tell you the English that you need (Hutchinson and Waters, 1996). For ESP and its development considerable contribution has been given by Tony Dudley-Evans and Maggie Jo St John (1998) who see ESP as a separate activity within the English Language Teaching. Evans and Maggie (1998) think that the main concerns of ESP have always been, and remain, to prepare learners to communicate effectively in tasks 
prescribed by their study or work situation. Robbinson (1991) also, speaks for ESP and she analysis it from the needs analysis approach, describing the primacy of needs analysis in defining ESP. ESP is 'normally goal directed' and that ESP courses develop from a needs analysis, which aims to specify as closely as possible what exactly it is that students have to do through the medium of English .

Based on this research of the literature, and our basic hypothesis for challenges of teachers/learners in ESP course, we created a survey questionnaire to conduct an interview with teachers of English for specific purposes. The focus of the survey was to gather data and information from teachers/learners experience with ESP.

\section{Research Aims and Methodology}

The aim of this research was to reveal students' preparedness to study ESP, their attitudes towards learning ESP and discuss the major problems for both ESP teachers and learners in the light of the subject specific content.

Second year students of Legal Studies Faculty of SEEU were the object of the study and the methods used were literature analysis, observation, a questionnaire and data analysis. Questions were compiled in cooperation with the Instructional Support Center. The idea was to gather from respondents as many data as possible for the challenges that teachers and learners come across in ESP course in English for Law. Most of the interviewed teachers and learners were chosen randomly and all of them were involved in the ESP courses.

\section{Challenges for the ESP Teacher/Learner}

One of the characteristics or even a critical feature of ESP is that a course should involve specialist language (especially terminology) and content. In the majority of cases ESP teachers are not specialists in the students' professional fields. That is why the primary issue in ESP teaching is the struggle to master language and subject matter. Teachers find themselves having to teach with texts whose content they know little or nothing about. In addition, the ESP teacher happens to be the syllabus designer and is responsible for the teaching material and evaluation. On the other hand the basic problem in designing a topic syllabus is that the ESP syllabus designer is not a specialist in the specific area (e.g. law), consequently he/she is not capable of deciding by himself/herself which topics to include in the syllabus to provide the required terminology. It is also very difficult for him/her to arrange the topics in the most suitable order. Care should be taken that the ESP classes do not precede the topics in the special subjects, as the ESP teacher is not a subject specialist, this can lead to misunderstanding. Moreover, if a topic has already been discussed in the special subject, this motivates the learners and gives them confidence to communicate or discuss.

Another problem is the text selection and adaptation. Not being a specialist in the specific area, the ESP teacher cannot decide by himself/herself how to adapt the text that the most important information in terms of subject matter will remain. The decision has to be made about the texts: on the one hand, the texts must not be too difficult, because neither the ESP teacher, nor the students have such a high level of professional knowledge; on the other hand, the text must not be too popular, because some learners have some confidence in their 
professional knowledge, and if the text is too easy for them in terms of subject matter, they tend to underestimate it in terms of language as well. In order to avoid such de-motivation, the text should contain some challenges which can activate the professional knowledge of the students.

The lack of close cooperation and coordination between content lecturers and the designers of the study programs, is a problem that still exists. Content lecturers should have more responsibility for introducing students and training them in a particular discipline. Developing home assignment or oral examination tasks together with content experts could be a great help for ESP teachers.

Moreover, students start to study ESP from the third semester. In the ESP course the students are expected to have at least an intermediate level of general English. In practice we have to deal with mixed-ability groups in terms of both level of language competence and professional competences. Some students are very good at English; other students are very good at professional areas (i.e., know carrier content very well but do not possess good command of English). The first group wants to practice their general English and is quite disappointed by the matter-of-fact style of technical English. For example doing boring reading tasks for a certain topic may cause them to lose motivation for studying ESP. The group who feels confident in their professional field has much stronger motivation for studying ESP. Though if some of them do not have good knowledge of general English they would like to spend much more time studying grammar, revising tenses, articles, etc

If the English teacher is not competent in law and the learners are not competent in English and

Law, how can they possibly communicate in the different aspects of the learning/teaching process? How

can an ESP teacher cope with the issues he/she meets in his/her job?

Kennedy and Bolitho (1990) provide part of the answer. According to Kennedy and Bolitho (1990) ESP teachers do not need to learn specialist subject knowledge. They require three things only:

- A positive attitude towards the ESP content;

- A knowledge of the fundamental principles of the subject area;

- An awareness of how much they probably already know;

In other words, as I understand this, the ESP teacher should not become a teacher of the subject matter, but rather an interested student of the subject matter. Nevertheless, some teachers are able to develop sufficient knowledge of a subject to teach confidently from the subject-specific texts. But even the most dedicated ESP teacher will realize that his knowledge of a subject has limits and may feel the need for closer cooperation with the subject teacher, perhaps developing a team-teaching program.

Other research has shown that the more content-specific the course, the more students will find it useful and be motivated. Barbara Gross Davis (1993) describes subject-specific approach as something which motivates students to learn as it is based on students' specific needs for future occupational roles.

Furthermore Brabara Gross Davis (1993) says that students perform best when the level of English is slightly above their current competence level in their field of study. If the 
task is to easy, it promotes boredom and may communicate a message of low expectations or a sense that the teacher believes the student is not capable of better work. A task that is too difficult may be seen as unattainable, may undermine self-efficacy, and may create anxiety.

\section{Respondents' results and Data Analysis}

The aim of the survey was to find out students' opinion about their preparedness to study the content of ESP course. The respondents were second year students who study ESP at SEEU Faculty of Law. The participants were the students graduating in Faculty of Legal Studies.

There were 85 participants altogether. The research employed a questionnaire on students' attitudes towards learning ESP. The students were asked to answer questions. For 5 questions students were expected to tick the appropriate answer according to the Scale: Completely, Not at all, and Partly.

The last question was optional. Students had to comment about leaning ESP concerning subject matter of ESP course. The survey results are shown in Table 1.

Table 1. Students' answers about learning ESP (\%)

\begin{tabular}{|l|l|l|l|}
\hline \multicolumn{5}{|c|}{ Completely Not at all } & $42 \%$ \\
\hline $\begin{array}{l}\text { 1. Do you have enough } \\
\text { knowledge of a foreign } \\
\text { language to learn ESP? }\end{array}$ & $49 \%$ & $9 \%$ & $18 \%$ \\
\hline $\begin{array}{l}\text { 2.Do you understand the } \\
\text { content of ESP course? }\end{array}$ & $68 \%$ & $14 \%$ & $46 \%$ \\
\hline $\begin{array}{l}\text { 3.Do you understand ESP } \\
\text { words and collocations } \\
\text { needed for specialty? }\end{array}$ & $52 \%$ & $2 \%$ & $56 \%$ \\
\hline $\begin{array}{l}\text { 4.Can you discuss about your } \\
\text { specialty related topics? }\end{array}$ & $29 \%$ & $15 \%$ & $41 \%$ \\
\hline $\begin{array}{l}\text { 5. Does the content of ESP } \\
\text { course meet your learning } \\
\text { needs? }\end{array}$ & $46 \%$ & $13 \%$ & \\
\hline
\end{tabular}

The table demonstrates that about half of students (49\%) have sufficient knowledge of a foreign

language to learn ESP, $42 \%$ of students partly claimed to have enough knowledge of a foreign language to study ESP. It was satisfying to know that in general students are either ready or partly ready to study ESP at college and learning ESP does not cause very big problems for them. Nevertheless, $42 \%$ will have difficulties and $9 \%$ will have great difficulties in learning which can lead to challenging situation for both teachers and students in the classroom. 
For the second question, $68 \%$ of the respondents understand the carrier content of ESP course, $18 \%$ understand it partly and $14 \%$ state that they do not understand carrier content of ESP course. So, almost one third of the respondents state that it is difficult to understand the carrier content of the ESP course. This can be explained by the fact that students learn ESP from the third semester and not yet prepared and naturally the ESP classes precede the topics in specific disciplines.

It can be seen from Table 1 that $52 \%$ of the respondents understand ESP words and collocations needed for specialty, $46 \%$ of the respondents understand them partly and $2 \%$ do not understand them at all. As students have ESP course from the third semester they have not acquired the knowledge of the specialty subjects yet and this problem can be effectively solved by consulting the subject specialists.

Only $29 \%$ of the respondents answered that they are able to discuss on specialty related topics, $56 \%$ can do it partly and $15 \%$ are not able to discuss about their specialty related topics at all. This fact is shocking as inability to communicate and discuss in professional field, will leave the goals of the ESP course - to communicate in professional field - unfulfilled. And if we add the fact that for almost half of the respondents $46 \%$ understanding ESP words and collocations causes problems as well, we can make an assumption that it is quite challenging for the students to have ESP course from the third semester.

Table 1 reveals that the content of ESP course meets learning needs for $46 \%$ of the respondents, whereas $13 \%$ of the respondents answered that the course does not meet the needs of the learners, $41 \%$ of the respondents count the course as partially fulfilling their learning needs. That is alerting information because an ESP course should satisfy the specific needs of particular learners. Important things which must be considered when analyzing learning needs are who the learners are, their level of general English, their level of professional knowledge, their expectations about the course, etc.

The last question was optional. The students were asked to comment about learning/teaching ESP with

regard to carrier content of the ESP course. 30 students answered this last question. The majority number 24 of students wrote that ESP course is excellent or useful. Two students complained that content of the texts is sometimes too old-fashioned; though later one student added that it is not the most important in language acquisition. Two students complained that ESP course is too short. One student complained that the level could be more difficult. These results provided very useful opinion from the learner as regards their challenges in the ESP. Teachers of ESP should consider these evidence in their ESP courses. 


\section{Conclusion}

With specific purposes in mind, the learners know clearly what they need to learn, and they will learn with high motivation what they find useful for their work later or at present. For this reason, an ESP teacher should be aware of the learners' needs as not to introduce irrelevant materials to the course.

It is worth analyzing the reasons why the content of ESP course does not meet students' learning needs more fully and try to solve these problems. Very important decisions have to be made by the teacher -selection and adaptation of the ESP material, the selection of the task types and the designing the tasks for the students, choice of those teaching methods that would suit the learners' needs in the best way.

Teachers may have difficulty teaching both language and content but in the real world people learn language and content simultaneously, and teachers need to be able to address both language and content within their classrooms.

One more thing that ESP teachers can do is to try to develop their competence in students' particular professions. The experience of teaching and knowledge of students' specialties gives the ESP teacher confidence. However, teaching/learning ESP includes much more than the teaching of English through specific material and content. Teaching ESP combines development of linguistic skills together with acquisition of specific information. Even homework assignment should be associated both with the specialty and with the skills mentioned.

\section{Recommendations}

- In higher-education settings, it is very important for lecturers in English for Specific Purposes

to establish channels of communication with content lecturers and study program designers.

- ESP teachers should not try to teach the subject itself (he/she would probably not be able to

anyway), but should strongly advise the students to discuss the matter with his/her subject teacher.

- A mixture of skill-based and topic-based approaches seem to be more relevant to the needs of the learning situation to satisfy the learning needs of the ESP course. 


\section{References}

1. Hutchinson T., Waters A. English for Specific Purposes: Cambridge University Press. 1996.

2. Tony Dudley-Evans, Maggie Jo St John Developments in English for Specific Purposes: Cambridge University Press.1998

3. Kennedy C., Bolitho R. English for Specific Purposes. Macmillan Publisher Ltd. 1990.

4. Barbara Gross Davis Motivating Students Jossey-Bass Publishers: San Francisco, 1993

5. http://www.espbooks.com 